\title{
A comprehensive hydro-geomorphic study of cliff-top storm deposits on Banneg Island during winter 2013-2014
}

\author{
Autret Ronan ${ }^{1,{ }^{*}}$, Dodet Guillaume ${ }^{1}$, Fichaut Bernard ${ }^{1}$, Suanez Serge ${ }^{1}$, David Laurence ${ }^{1}$, \\ Leckler Fabien $^{2}$, Ardhuin Fabrice ${ }^{3}$, Ammann Jérôme ${ }^{4}$, Grandjean Philippe ${ }^{5}$, Allemand Pascal ${ }^{5}$, \\ Filipot Jean-François ${ }^{6}$
}

${ }^{1}$ IUEM, Université de Bretagne Occidentale, LETG Brest Géomer, UMR 6554 CNRS, 29280 Plouzané, France

${ }^{2}$ Service Hydrographique et Océanographique de la Marine, 29200 Brest, France

${ }^{3}$ Laboratoire d'Océanographie Physique et Spatiale, UMR 6523 CNRS-Ifremer-UBO-IRD, 29200 Brest, France

${ }^{4}$ IUEM, Université de Bretagne Occidentale, Laboratoire Domaines Océaniques, UMR 6538 CNRS, 29280 Plouzané, France

${ }^{5}$ Université de Lyon 1 et ENS-Lyon, UMR5570 CNRS, 69662 Villeurbanne, France

${ }^{6}$ France Energies Marines, 15 rue Johannes Kepler, Site du Vernis, Technopôle Brest-Iroise, 29200 Brest, France

*Corresponding author : Ronan Autret, email address : ronan.autret@univ-brest.fr

\begin{abstract}
:
Large clastic cliff-top storm deposits (called CTSDs) are one of the most remarkable signatures that characterizes extreme storm wave events on coastal cliffs. Hence, the study of CTSDs is of key importance for understanding and predicting the impacts of extreme storm wave events on rocky coasts or establishing proxies for storm intensity. The present study uses new data including hydrodynamic measurements in both deep and intertidal waters, and records of CTSDs displacement and deposition across Banneg Island during the stormy winter 2013-2014. Two drone-based surveys were carried out in January 2013 (pre-storms) and in April 2014 (post-storms). In addition, complementary field observations were carried out during the winter, providing a comprehensive and detailed dataset. Concerning the hydrodynamic measurements, nine pressure sensors deployed along four cross-shore profiles on the western coast of the island, recorded wave and water level conditions between December 2013 and April 2014. Aerial orthorectified photographs and digital elevation model of differences provide a detailed spatial description of cliff erosion and the reworking of cliff-top storm deposits. After the storms, 172 fresh scars corresponding to quarrying in the bed rock were localized above high spring tide water level, 507 blocks were transported up to $40 \mathrm{~m}$ inland, at altitudes of 8 to 14 $\mathrm{m}$ above mean sea level, and the tracks of 170 of them were identified. The water levels and wave parameters estimated from the pressure sensor measurements provided accurate information on the maximum water elevation reached during the largest storms at the sensor locations and were extrapolated to provide run-up elevation along the four survey profiles for the whole winter 2013-2014. The results demonstrate that a large number of overwash episodes occurred, at times of high tides and energetic waves. These episodes generally correspond to morphological changes. This study confirms the major role played by extreme storm wave events on CTSDs quarrying, transport, and deposition on
\end{abstract}


Banneg Island, and clearly identify the events of major evolutions.

\section{Highlights}

- High resolution data provide new insights on CTSDs dynamics at Banneg Island. Cliff-top erosion and CTSDs reworking are thoroughly analyzed. Seven extreme water level events are identified through the analysis of hydrodynamic data. Pressure measurements in the upper swash zone are used to calibrate an empirical run-up formula.

Keywords : Cliff-top storm deposit, Block transport, Extra-tropical cyclone, Run-up, Coastal erosion, Brittany 


\section{Introduction}

On rocky cliffed coasts facing deep water and exposed to storm waves, large blocks may accumulate on top of the cliffs. On the European North Atlantic coasts such accumulations are known as cliff-top storm deposits (CTSDs) due to their mobility during storm wave activity (Hall et al., 2006; Fichaut and Suanez, 2011). The formation of these deposits is both controlled by the lithostructural characteristics of the cliff allowing the quarrying of blocks, and by the hydrodynamic conditions that induce the uplift, transport and deposition of these blocks on the cliff-top (Hall et al., 2006; Fichaut and Suanez, 2011; Paris et al., 2011). Hence, the nearshore bathymetry also plays an important role in CTSDs formation as it affects the propagation and dissipation of the incident wave energy (Hansom et al., 2008). Within the North Atlantic basin, storm-induced CTSDs were described in Brittany (Fichaut and Suanez, 2008; Suanez et al., 2009), British Isles, Republic of Ireland (Williams and Hall, 2004; Cox et al., 2012) and Iceland (Etienne and Paris, 2010; Autret et al., 2016). These authors provided evidences that tsunami were not responsible of the formation of these deposits during the last centuries. However, most of these studies were based on qualitative observations of morphological nature (historic maps, aerial photographs, topographic and sedimentological measurements, geomorphological indicators) and did not include hydrodynamic measurements (Paris et al, 2011; Richmond et al., 2011; Cox et al., 2012). Some authors derived the hydrodynamic conditions inducing these processes from mathematical models based on lithostructural and morphometric characteristics (Nott, 2003; Hansom et al., 2008; Nandasena et al., 2011; Lau et al., 2015). Although these models can be used to estimate the magnitudes of the water level and velocity necessary for the quarrying, transport and deposition of blocks, they can hardly characterize the realistic hydrodynamic conditions occurring during storm events (Naylor et al., 2016). Therefore, a better understanding of the link between the action of these hydrodynamic processes and their implications in terms of 
morphosedimentary response appears as a key issue (Goto et al., 2011; Scheffers et al., 2012; Naylor et al., 2014). Similarly, in several studies focusing on the quantification of extreme water levels causing cliff-top submersion and/or transport of blocks, the methodological approach is based only on the use of theoretical equations including run-up, without validation based on field measurements (Suanez et al., 2009; Fichaut and Suanez, 2011; Carbone et al., 2013). As reported by Ardhuin et al., (2011) and Sheremet et al., (2014), the characteristics of hydrodynamic processes acting on the elevation of water level (setup and run-up) along very steep cliffs make extremely difficult the use of equations established on the sandy beaches. It is therefore necessary to perform high frequency field measurements in order to calibrate these theoretical formulas for each specific coastal environments. The ongoing work on extreme water levels and their geomorphological impacts on rocky coasts in a context of climate change is of strong interest for coastal managers (Naylor et al., 2014). Moreover, hydro-geomorphic study combining morphodynamic and hydrodynamic data are needed to improve mathematical and numerical modelling of coastal boulder transport (Nandasena et al., 2011; Lau et al., 2015; Kennedy et al., 2016).

For the European North Atlantic coastal zone, the winter 2013-2014 was particularly morphogenetic. This winter was characterized by a cluster of storms that hit the coasts of Western Europe (Matthews et al., 2014; Wadey et al., 2014; Dissanayake et al., 2015, Masselink et al, 2015). Based on a 67-year (1948-2015) wave model hindcast, Masselink et al. (2016) showed that winter 2013-2014 was the most energetic winter along the European Atlantic coast since at least 1948, inducing extensive coastal impacts along the coastline. The 110-km long Gironde coast (SW France), suffered unprecedented beach and dune erosion (Castelle et al., 2015). On Brittany coasts, shoreline have also been severely impacted by at least twelve major storms, inducing an average shoreline retreat of sandy/shingle beaches 
reaching $-6.3 \mathrm{~m}$, with a minimum of about $-0.2 \mathrm{~m}$ and a maximum of $-30.1 \mathrm{~m}$ (Blaise et al., 2015).

Although recorded on the Aran Islands (Erdmann et al., 2015), the effects of the winter 20132014 on CTSDs of the Western European coast have not been studied yet. Our paper provides a comprehensive assessment of the impacts of the 2013-2014 winter storms on CTSDs on Banneg Island, based on hydrodynamic measurements and morphological surveys. The highest water levels that occurred during winter 2013-2014 are first identified from the wave and water level measurements. Secondly, field measurement are used to calibrate the run-up formula of Stockdon et al. (2006) in order estimate the flooding events that may have caused CTSDs quarrying and/or transport. Thirdly, a diachronic analysis of CTSDs morphosedimentary changes allows the quantification of quarrying, displacement and deposition of megablocks over three periods during the winter. Finally, a description of the processes related to the impact of waves and flooding on the dynamics of CTSDs is provided, as well as a quantification of erosion processes during the whole winter period.

\section{Study area}

\subsection{Geological and geomorphological setting of Banneg Island}

The archipelago of Molène is located in the Iroise Sea, off the western tip of Brittany peninsula (Fig. 1A-B). It consists of 18 main vegetated islands and 111 small islets and reefs amount to a surface of land of 229 ha lying above highest astronomical tide (AHAT) and corresponding to the emerged part of a shallow submerged plateau covering 15.286 ha between 0 and $25 \mathrm{~m}$ above mean sea level (AMSL) (Fig. 1B). 
Banneg Island lies in the north-western edge of this archipelago and is separated from Ouessant Island by the deep Fromveur Channel (Fig. 1B). This island is the largest of a group of four islands that are Banneg itself, and southward Enez Kreiz, Roc'h Hir and Straon Vraz (Fig. 1D). The four islands are separated by saddles (due to erosion) oriented from WSW to ENE corresponding to one of the main fault axis in the archipelago of Molène (Le Gall et al., 2014). Between Banneg, Enez Kreiz and Roc'h Hir, low-lying areas emerge at low tide, while the island of Straon Vraz is always isolated from the others whatever the tidal level.

Banneg Island constitutes a granite batholith, oriented north-south, $0.8 \mathrm{~km}$ long and 0.15 to $0.35 \mathrm{~km}$ wide (Fig. 1C). The western coast is cut into sub-vertical cliffs made up of a series of high headlands (16 m to $20 \mathrm{~m}$ AMSL) with steep slopes (> 50\%), and lower (12 m to $13 \mathrm{~m}$ AMSL), less steep cliffs in embayments (15 to 35\%). As indicated by Suanez et al. (2009) and Fichaut and Suanez (2008, 2011), these morphological characteristics and evolution of the cliffed west coast are related to the structure and joint system of the bedrock. At the headlands, which constitute the summits of the island, massive jointing organized in a loose orthogonal pattern make the rock body more resistant to marine erosion. They generally exhibit high towering rocky outcrops, except for Lachat Amaric Ler headland between the south and centre-south areas (Fig. 2). In this area, the upper part of the cliff shows a higher density of fine sheet horizontal joints that cut the rock face into large horizontal slabs and shape the headland in rounded domes. In contrast, at the embayments the granite has very dense sheet jointing from the middle to the upper cliff face, promoting large horizontal or box-shaped clasts of smaller size. Therefore, these lithostructural characteristics make the embayments much more sensitive to marine erosion. However, at the base of cliffs along the embayments, massive, orthogonal jointing may engender enormous quadrangular clasts 
accumulated on the tidal zone as an armor layer of rounded blocks or quadrilateral-shaped blocks with smoothed edges, weighing from one to several dozens of tons.

More than $1000 \mathrm{~m}^{3}$ of CTSDs, whose individual weights vary from several kilograms to several tons (up to 42 tons), have been quarried and transported from the cliff-top (Fichaut and Suanez, 2008; Suanez et al., 2009). They are accumulated mainly at the rear of the cliff top edge backing embayments. The furthest inland accumulation lies $100 \mathrm{~m}$ from the western cliff edge on a slope that gently dips towards the eastern coast of the island. CTSDs have different forms and organization depending on the sector. They may locally correspond to a spread of isolated blocks. However, more often they form clusters or rectilinear ridges parallel to the cliff edge (like in the centre and north areas), or arcuate trains at the rear of embayments, mirroring the area's coastline (like in the centre-south and south areas). More than 60 accumulations lying at altitudes between $7 \mathrm{~m}$ and $14 \mathrm{~m}$ AMSL and up to $75 \mathrm{~m}$ from the edge of the cliff (like in the centre-north area) were inventoried for the entire island (Fig. 2). The largest ridge is located in the centre sector; it is $2.5 \mathrm{~m}$ high, stretches over a $60 \mathrm{~m} \times 20$ $\mathrm{m}$ surface area, and it has a volume of around $350 \mathrm{~m}^{3}$. In this sector, a $1 \mathrm{~m}$ deep gully has been dug over time by erosion of the bedrock (Fig. 1D). This erosion form corresponds to a topographic saddle that crosses the island from west to east. The low altitude of the gully and the eastward slope facilitated the passage of particularly high velocity flows during submersion of the island (Fichaut and Suanez, 2011). These flows are expected to be the transporting agent leading to the construction of a delta of blocks located directly at the mouth of the gully on the eastern coast (Fig. 1D). Locally these CTSDs accumulations are deposited in double or triple parallel ridges, separated by areas of turf or rock surfaces, like in the south and the centre - centre-south part of the island (Fig. 2). In triple ridges, the accumulations closest to the cliff edge are the largest ones. 


\subsection{Hydrodynamic conditions}

The Iroise Sea is characterized by a semidiurnal macro-tidal regime with tides ranging from $2.5 \mathrm{~m}$ in neap tide conditions to $8.2 \mathrm{~m}$ in spring tide conditions (SHOM, 2014). Moreover, the irregular coastline and the presence of numerous islands induce very strong tidal currents in this area. Given its exposed location and its proximity to the mid-latitudes storm pathway, the Iroise Sea experiences the most energetic sea states found on the French coasts of Europe (Boudière et al. 2014). Wave measurements recorded off Ouessant Island by BEA III wave buoy (Fig. 1A) between 1995 and 2011 show that the mean and maximum significant wave heights $\left(\mathrm{H}_{\mathrm{s}}\right)$ reached $2.0 \mathrm{~m}$ and $12.1 \mathrm{~m}$ respectively, and the mean and highest maximum wave heights $\left(\mathrm{H}_{\max }\right)$ reached $3.2 \mathrm{~m}$ and $18.4 \mathrm{~m}$, respectively. However, these values were measured by an 80 -tons navigational buoy that is not designed to follow the wave movements and thus underestimates extreme wave heights (Benoit et al., 2006). As indicated by Blaise et al. (2015), the highest $\mathrm{H}_{\max }(23.5 \mathrm{~m})$ was recorded on February 5, 2014 by Les Pierres Noires wave buoy situated south of Molène archipelago (Fig. 1B).

Around Banneg Island, the maximum tidal range is $8 \mathrm{~m}$ and tidal currents in the Fromveur Channel can reach $4 \mathrm{~m} \cdot \mathrm{s}^{-1}$ during spring tide conditions. With an average shoreface slope of $4 \%$, the western coast of Banneg Island is flanked by 50 m-deep waters at only $1.2 \mathrm{~km}$ from the coastline and incident waves are slowly attenuated when they reach the island. However, due to the sheltering effect of Ouessant Island, most waves reach the island with an Hs approximately $40 \%$ lower than west of Ouessant (Ardhuin et al., 2011) and with a WSW direction. Ardhuin et al. (2012) showed that the strong tidal currents occurring in the Fromveur Channel have a strong influence on the propagation of incident waves due to current-induced refraction, Doppler shifting of frequencies and current-gradient enhanced 
dissipation. In addition, energetic waves observed along the west cliff of the island were shown to be responsible for the excitation of very large sea level oscillations with typical periods of 2 to 4 minutes and significant wave height exceeding 2 meters (Sheremet et al., 2014).

\section{Materials and methods}

\subsection{Hydrodynamic measurements}

\subsubsection{Field work and data processing}

From December 2013 to April 2014, a field campaign was carried out at Banneg Island in order to characterize the winter hydrodynamic conditions. Offshore directional wave spectra were provided every $30 \mathrm{~min}$ by a directional waverider (Datawell DWR-MkIII, hereafter referred to as DWR) moored $1.5 \mathrm{~km}$ off the island. Nearby, in approximately $50 \mathrm{~m}$ water depth, a bottom-mounted pressure sensor (Seabird Electronics SBE26+, hereafter referred to as SBE) provided 20-min averaged water levels every two hours. In addition, height pressure transducers (Ocean Sensor System, OSSI-010-003C, hereafter referred to as OSSI) were installed on the western cliffs of the island, along four cross-shore profiles located in embayments fronting the four main block deposits (north, centre, centre-south and south sectors, referred to as N, C, CS and S, respectively) (Fig. 1C). Each profile is composed of one "bottom" sensor located under the mean sea level (labeled with a "b" subscript) and one "top sensor" located above the highest astronomical tide (labeled with a " $\mathrm{t}$ " superscript). 30min averaged pressure data was converted into mean water elevation assuming hydrostaticity after subtracting the atmospheric pressure measured at the Stiff weather station on Ouessant Island (Fig. 1B). Bulk wave parameters were derived from 30-min-long pressure time-series acquired at 5Hz, decomposed into 50\% overlapped, detrended and tapered (Hanning window) segments of 1024 samples used to compute pressure spectra. The pressure spectra were then 
converted into elevation spectra through linear wave theory. The DWR, SBE and OSSI instruments hence provided mean wave parameters, mean water levels and instantaneous water levels continuously every $30 \mathrm{~min}, 30 \mathrm{~min}$ and $0.2 \mathrm{~s}$, respectively.

In order to complete this dataset, a harmonic analysis was performed on a 1-year (09/201309/2014) time-series of water elevation recorded at Le Conquet tide gauge. The astronomical tide synthesized from the resulting amplitude and phases was then subtracted to the measured tide in order to obtain the atmospheric surge during winter 2013-2014.

\subsubsection{Identification of extreme water level events}

Past observations of CTSDs quarrying and displacement at Banneg Island (Fichaut and Hallégouët, 1989; Fichaut and Suanez, 2011) showed that morphogenic events were systematically associated with very energetic waves combined with high water levels. In order to identify, within the almost uninterrupted sequence of storms of winter 2013-2014, the events that impacted Banneg Island morphology, we define an extreme water level (EWL) event as a 36-hr period limited by two low tides, during which $\mathrm{H}_{\mathrm{s}}$ at DWR and the water level at SBE exceeded, simultaneously and at least once, the $\mathrm{H}_{\mathrm{s}} 10 \%$ exceedance level $(4 \mathrm{~m})$ and the mean high water spring level ( $3 \mathrm{~m}$ AMSL), respectively. The $36 \mathrm{~h}$ duration was chosen to cover the synoptic scale of each storms and thus the different combinations of water levels and significant wave height, which did not necessarily reach their maximum simultaneously. 


\subsubsection{Extrapolation of water levels to obtain run-up time-series}

Pressure sensors deployed in the upper swash zone provide information on the local water levels every time they are submerged by a swash bore. On steep slope environments, this data corresponds to a lower bound of the actual run-up, defined as the water level at the wet-dry boundary, and can be used to fit an empirical predictor of the elevation systematically exceeded by the run-up, as in Ardhuin et al. (2011). In the present study, we want to predict the actual run-up in order to accurately determine flooding events on Banneg Island. We thus developed a method to adjust an empirical run-up formula against local measurements, based on the following idea: when the run-up height exceeds the instrument's position, the latter is necessarily wet (and measure high variance swash bores), whereas it is necessarily dry (and measure low variance noise) when the run-up height does not reach it.

A usual measure of the run-up is the water level at the wet-dry boundary that is exceeded only $2 \%$ of the time, $\mathrm{R}_{2}$. Based on observations collected on sandy along-shore uniform beaches with foreshore slopes $\beta_{\mathrm{f}}$ between 2 and 10\%, Stockdon et al. (2006) decomposed $\mathrm{R}_{2}$ into a set-up (mean sea level) and a swash excursion that is partly due to infragravity waves. They arrived at the empirical relation:

$$
R_{2}=\alpha\left(0.35 \beta_{f}\left(H_{0} L_{0}\right)^{1 / 2}+\frac{\left[H_{0} L_{0}\left(0.563 \beta_{f}^{2}+0.004\right)\right]^{1 / 2}}{2}\right)
$$


where $\mathrm{H}_{0}$ and $\mathrm{L}_{0}$ are the offshore significant wave height and wave length respectively, and $\alpha$ is a constant obtained by regression analysis between predictions and observations for their large data set ( $\alpha=1.1$ in Stockdon et al. 2006). In the present study, we will assume that the empirical runup formula derived by Stockdon et al. (2006) for sandy beaches also applies to rocky shores and we will use $\alpha$ as a calibration factor specific to each sector. Since this formula has not been proven yet to apply to steep rocky environment, the runup results will only be discussed qualitatively. The foreshore slope $\beta_{f}$ is known to vary significantly over a tidal cycle in macrotidal environments (Ruessink et al, 1998; Suanez et al. 2015) such as Banneg Island. Consequently, a time-dependent slope was computed along each profile over a shifting 20-m wide segment centered at the intersection between the offshore water level and the topography.

In order to calibrate Equation (1) against observations, we computed for each profile $17 \mathrm{R}_{2}$ time-series with $\alpha$ ranging from 0.4 to 2 (with a 0.1 increment). A binary parameter $B_{\text {pred, }}$ associated to these time-series, was given the value 1 or 0 whether the predicted runup exceeded or not the elevation of the corresponding top sensor. Then we computed time-series of $2 \%$ exceedance level $\left(\mathrm{EL}_{2}\right)$ from the top sensors measurements along 10-min sliding windows and flagged a binary parameter Bobs as 1 or 0 whether $\mathrm{EL}_{2}$ was positive or null. For each $R_{2}$ time-series, we determined an agreement score $S(\alpha)$ as:

$\mathrm{S}(\alpha)=\frac{1}{N} \sum_{1}^{N} \mathrm{~B}_{\text {obs }} \times \mathrm{B}_{\text {prod }}(\alpha)$ 
where $\mathrm{N}$ is the number of times when either $\mathrm{B}_{\text {obs }}$ or $\mathrm{B}_{\text {pred }}$ were equal to 1 . For each sector, the optimal factor $\alpha$ corresponded to the best agreement score between run-up predictions and local measurements (Fig. 3). Finally, the offshore water level was added to each calibrated run-up time-series to provide run-up predictions relative to the still water level.

\subsection{Geomorphological survey}

The geomorphological survey focused primarily on supratidal areas of the western part of the island, including cliffs, wave-scoured platforms and ridges or clusters of CTSDs. As indicated by Blaise et al. (2015), rough sea conditions between December 2013 and March 2014 did not permit to carry out a high frequency survey of CTSDs morphological changes during the stormy periods. Two Unmanned Aerial System (UAS) based surveys were carried out over the island on January 1, 2013 (survey 1) and April 8, 2014 (survey 4) respectively. In addition, ground oblique photographs and kite aerial oblique photographs were collected during two intermediate field missions on January 14, 2014 (survey 2) and February 18, 2014 (survey 3). Note that all the altitudes and elevations given in the text without any precision (e.g. AMSL) are provided in the RGF93 reference system, with the " 0 " value corresponding to the topographic datum of the French Geographic Information Institute (IGN), located approximately $50 \mathrm{~cm}$ under the actual mean sea level near Banneg Island.

\subsubsection{Field measurements}

The two UAS-based surveys (survey 1 and 4) were carried out along the western cliffed coast of Banneg Island in January 2013 and in April 2014. They provided high-resolution orthorectified aerial imagery and digital elevation models. Aerial imagery was acquired by means of a Nikon D700 camera suspended from a DS6-1200 Hexacopter (Fig. 4B). Three flights at elevations ranging from 80 to $85 \mathrm{~m}$ pre-programmed via the Mikrokopter software 
package were necessary to cover the area of interest ensuring optimal images overlap (Fig. 4A). The intervalometer function was set to acquire footages every $5 \mathrm{~s}$ at $1.5 \mathrm{~m} . \mathrm{s}^{-1}$ horizontal speed along two parallel flight lines to have an image side lap higher than $60 \%$. At the same time, 50 ground control points (GCPs) were surveyed by a Topcon Hyper V Differential GPS in Real Time Kinematics (RTK) mode. $\mathrm{X}, \mathrm{Y}$ and $\mathrm{Z}$ coordinates were referenced to EPSG 2154. These GCPs were white laminated paper plates fixed on the floor by tent pegs to ensure that their positions were the same during the RTK measurements and the flight time (Fig. 4A).

Two additional surveys (survey 2 and 3) based on ground photographs and kite aerial oblique photographs were carried out on January 14, 2014 and February, 152014 to collect data at intermediate dates within the winter. These additional photographs were compared with preexisting ground photographs and provided qualitative information about geomorphological changes occurring within the winter period.

\subsubsection{Structure from Motion (SfM) photogrammetric process}

To perform the SfM photogrammetric process, we used Agisoft Photoscan Professional software following the recommended procedure supplied by the company (Agisoft, 2013). For each UAS-based surveys, three chunks (corresponding to the three flights) of about 80 images were processed separately prior to be merged. Finally, an orthorectified aerial image, a Digital Elevation Model (DEM) and a dense point cloud were produced for both missions (Table 1). 


\subsubsection{Orthorectified aerial imagery and DEM processing}

Geomorphological changes were analyzed from orthorectified aerial images collected before and after winter 2013-2014, allowing the characterization of block movements. Prior to the winter, 4741 blocks were identified and hand-contoured from the pre-winter orthorectified aerial images with ESRI ArcGIS software. In addition, 677 significant indicators of geomorphological changes, such as removed blocks $(n=499)$ and quarrying sockets $(n=178)$, were inventoried. At the same time, block trajectories and directions were digitized $(n=175)$ by linking the polygons centroid of the pre- and post-winter surveys. The dimensions $(a, b, c$ axis), the shape and the weight of these 175 blocks were measured on the field to obtain their granulometric characteristics. These geographical and granulometric attributes resulted in a relevant and useful geostatistical dataset.

The volumetric approach was performed by computing the differences in surface elevation from pre- and post-winter DEM with the Geomorphic Change Detection software (Wheaton et al., 2010). Computation of volumetric changes were achieved on four areas of interest located at the N, C, CS and S sectors of the island. The selection of these areas was based on the location of the main clusters and ridges, with the constraint to be aligned with the OSSI cross-shore profiles. The differences calculation of pre- and post-winter DEM gridded at $3 \mathrm{~cm}$ was executed at a $90 \%$ confidence interval. The choice of the threshold used to calculate the DEM of difference (DoD) was based on the need to highlight the most significant changes, while attenuating the contribution of topsoil erosion and phonologic stages of the vegetation. While the procedure performed well for the C, CS and S sectors, it failed in the $\mathrm{N}$ sector because of the poor quality of the pre-winter DEM in this area, due to insufficient density and overlap of photographs. 


\section{Results}

\subsection{Waves and water levels}

\subsubsection{Extreme water level events}

Winter 2013-2014 was characterized by an unusual succession of storms, which induced very large waves and atmospheric surges in the vicinity of Banneg Island, clearly visible in the hydrodynamic measurements (Fig. 5). The Hs time-series recorded by the DWR from midDecember 2013 to mid-March 2014, displays more than a dozen peaks exceeding $4 \mathrm{~m}$, one of them reaching $9 \mathrm{~m}$ on February 15. In terms of water level, the SBE measurements show several spring high tides levels close to the highest astronomical tide (4 m AMSL). These high water levels are likely caused by the recurrent storm surges associated with the exceptional cyclonic activity of winter 2013-2014. Indeed, the harmonic analysis performed at Le Conquet tide gauge revealed several surges reaching up to $0.5 \mathrm{~m}$, primarily caused by the inverse barometric effect, as shown by the negative correlation between the storm surge and the atmospheric pressure time-series.

As a consequence, several storm events occurred during periods of high water levels, associated with spring tides, atmospheric surges or a combination of both. It was, for instance, the case of the storms Anne from January 2 to January 4, Nadja from January 31 to February 2 and Christine from March 2 to March 4. Among the 13 events with $\mathrm{H}_{\mathrm{s}}$ higher than $4 \mathrm{~m}$, seven occurred when the high tide level was comprised between 3 to $4 \mathrm{~m}$ AMSL. These seven EWL events, highlighted with colored stripes on Fig. 5 and summarized in Table 2, are likely to have generated the largest waves and the highest water levels on Banneg Island. 
This assumption was confirmed by the analysis of the data recorded by the OSSI deployed on the island (Fig. 5 and 6). The Hs time-series computed from the bottom sensors $\mathrm{N}_{\mathrm{B}}, \mathrm{C}_{\mathrm{B}}, \mathrm{CS}_{\mathrm{B}}$, and $S_{B}$ get their 10 highest values within six of the seven previously defined EWL events, which do not necessarily correspond to the largest offshore Hs events (compare, for instance, Hs at DWR and at OSSI during Dirk storm on December 22-23, on Fig. 5). This owe to the weak bottom friction impact on the wave energy traveling in deeper water. Also, during large wave events and low tidal range, the OSSI remained in the saturated the surf zone, even at high tide. From north to south, the maximum Hs reached $4.4 \mathrm{~m}$ during Ulla storm, $5.6 \mathrm{~m}$ during Ulla storm, $5.7 \mathrm{~m}$ during Christina storm and $4.8 \mathrm{~m}$ during Anne storm, respectively. It is worth noting that the EWL event Gerhard did not generate one of the 10 largest Hs on the coast (except for the south profile), while Ruth storm (February 8-9) did, although it occurred during neap tide.

In terms of water levels, similar results were revealed by the analysis of the maximum elevations measured by the top and bottom sensors (Fig. 6). Due to their elevated locations, the top sensors measured only swash bores, and mostly during spring tides and storm periods. The highest water level was recorded by $\mathrm{CS}^{\mathrm{T}}$ on February, 5 at 8.15 am (Petra storm) and reached $12 \mathrm{~m}$, corresponding to a wave crest $4 \mathrm{~m}$ above the sensor. Such water levels, measured a few meters only from the cliff top and exceeding its height by more than a meter likely resulted in the partial flooding of the island. As for Hs, the 10 highest values occurred almost all within the EWL events. Interestingly, $\mathrm{C}^{\mathrm{T}}$ and $\mathrm{CS}^{\mathrm{T}}$ measured some of their highest elevations during Ruth storm (February 8-9), despite the neap tide conditions. The ranking of the 10 highest water levels measured by the top and bottom sensors revealed that Petra storm ranked first at five of the height sensors and probably was the most morphogenetic event of the whole winter. It is also worth noting that some of the sensors of sectors CS and S 
measured lower water levels during Petra storm than during Anne's storm, this latter ranking first at $\mathrm{CS}_{\mathrm{B}}$ and $\mathrm{S}_{\mathrm{B}}\left(\mathrm{S}^{\mathrm{T}}\right.$ stopped recording at the beginning of January and thus could not be included in the ranking analysis). Such differences between the sensor's records likely results from the contrasting bathymetry and shape of the coast at each profile, which control the wave propagation and breaking processes.

Although this observation-based analysis provided high-time-resolution information on the extreme water levels that occurred on Banneg Island during winter 2013-2014, the highly nonlinear wave dynamics in the swash zone is still too poorly understood to extrapolate these local measurements into run-up elevation. As a consequence, the calibration and use of an empirical formula for run-up was necessary to obtain a clearer description of the flooding episodes that have provoked CTSDs displacement during winter 2013-2014.

\subsubsection{Run-up estimation during winter 2013-2014}

The top sensors, located in the upper swash zone were used to calibrate the run-up formula of Stockdon et al. (2006) for each cross-shore profile, N, C, CS and S. The calibration factor of the run-up formula ( $\alpha$ in Equation 1) was determined by assessing the agreement between the swash events measured by the OSSI and the prediction given by the run-up formula for $\alpha$ values ranging between 0.4 and 2. Table 3 summarizes the scores obtained at each sensor for the 17 tested $\alpha$ values. The optimal factors for $\mathrm{N}, \mathrm{C}, \mathrm{CS}$ and $\mathrm{S}$ were $0.5,0.8,1.4$, and 0.9, respectively. These values differ significantly from the original value of 1.1 used by Stockdon et al. (2006). This difference might be attributed to the very chaotic nearshore bathymetry and the irregular coastline of the western shores of the island. Visual observations confirmed that the wave propagation and breaking processes were very different from one sector to another. For instance, the low value obtained for the $\mathrm{N}$ profile can be explained by the 
sheltering effect induced by the rocky outcrops that stands at the base of the profile and strongly attenuates the incident wave energy. On the contrary, the large value obtained for the CS profile may result from the funnel shape of the coast in this sector (Fig. 2) that focuses the wave energy

After calibrating the run-up formula against the top sensor's measurements, run-up time series were computed for each profile over the winter 2013-14 and added to the offshore tidal elevation. Fig. 7 shows the resulting total water elevations, including the tidal elevations and the run-up for each profile. For each sector, the highest runup were found either on February 5 (Petra) or February 14 (Ulla) 2014, and exceeded 6 m (05/02), 10 m (14/02), 16 m (05/02) and $11 \mathrm{~m}(05 / 02)$, at profiles $\mathrm{N}, \mathrm{C}, \mathrm{CS}$ and $\mathrm{S}$, respectively. This result partly corroborates the observations of maximum water elevations. Indeed, Petra storm induced the highest water levels at five of the seven sensors operating over the whole period (Fig. 6), However, the very high runups predicted for Ulla storm seem to be overestimated at profiles N, CS and S (Fig. 9), since this storm generated lower maximum water levels than other storms, according to the observations (Fig. 8). This difference likely reflects the limitation of empirical run-up formula based on offshore parameters, when applied to irregular coastlines and complex bathymetry.

In terms of island's submersion, the predicted run-up time-series indicate that the water level overtopped the cliff around 10 times in the C sector, more than 30 times in the CS sector, more than 5 times in the $\mathrm{S}$ sector, but none in the $\mathrm{N}$ sector. All the overtopping events occurred during EWL events, except in the CS sector where the predicted runup exceeded the cliff top also during neap tide conditions. It is also in the CS sector that the highest water levels occurred, exceeding sometimes the cliff top by more than $5 \mathrm{~m}$, which may have induced the torrential flooding of the inner part of the island, evidenced by the field 
observations (pre- and post-storm boulder position, patch of torn grass, large area of dried and bent grass delineated on Fig. 11A).

\subsection{Morphological changes}

\subsubsection{The winter 2013-2014 morphogenetic impacts on CTSDs}

The superposition and comparison of the pre- and post-winter orthorectified aerial images and DEM provided a very detailed analysis of the overall CTSDs morphological changes, in terms of processes (Fig. 8), kinematics (Fig. 9) and volumetric changes (Fig. 10).

Quarrying scars and sockets in the bed rock $(n=178)$ spread out from the base of the cliffs to the wave-scoured platform back of the cliff-top, where $40 \%(\mathrm{n}=63)$ of the sockets are located. Quarried volume represents about $80 \pm 40 \mathrm{~m}^{3}$. The largest sockets are located on the cliff slope. As mentioned earlier, the tracks of 20 of the 178 quarried clasts were identified

(Fig. 8). 18 of them moved up. Some were deposited a few meters inland from the quarrying location. However, most of these 20 blocks were transported to the base of the clusters or ridges standing inland from the cliff top. The remaining two fell down to the cliff base. It is the case of an 86 tons block, bounded on three faces, quarried at $9 \mathrm{~m}$ on the upper part of a $45^{\circ}$ slope cliff (Fig. 11B). The tracks of the 158 other quarried blocks are unknown, but the difference between the number of deposited blocks of unknown origin $(n=534)$ and the number of loose blocks removed $(n=343)$ shows that almost all of them moved up to the top of the cliffs or further inland. The difference $(n=191)$ probably comes from the quarried blocks, which may have been broken into pieces during transport (Fig. 8). 
Regarding the loose blocks, apart from one rounded block ( 1 ton) initially located below high tide level that was transported up to the cliff, all the loose block removal occurred above the high spring tide level. $75 \%$ of the transported loose blocks were removed at altitudes higher than $8 \mathrm{~m}$ corresponding to the minimal height of the cliff-tops (Fig. 12). 10 blocks weighing from 2 to 14 tons were removed at elevations exceeding $10 \mathrm{~m}$. For the 175 blocks whose track were identified there is no correlation between their mass and the altitude of removal neither the distance of transport (Fig. 12).

In the north sector, which is an embayment sheltered by a promontory and skerries, all quarrying sockets are located at the base or on the lower part of the cliffs. The clusters sitting on the turf inland from the cliff edge were left undisturbed except at the head of a gully that enhanced wave action, where a dozen of blocks located at altitude of $9 \mathrm{~m}$ were pushed 1 to 3 $\mathrm{m}$ inland. In the centre-north sector some quarrying occurred on the cliffs under $8 \mathrm{~m}$. The clusters remained inactive but the entire area was submerged. 40 loose blocks were transported on the turf on the top and the eastern slope of the island by the exiting water flow as indicated by identified tracks all oriented eastward. 3 blocks exceeding $1.5 \mathrm{t}$ moved $15 \mathrm{~m}$ or more inland.

In the centre sector the stepped cliff culminates at $8.3 \mathrm{~m}$, and is backed by a $15 \mathrm{~m}$ flat wide wave-scoured platform (Fig. 2A). Inland, 2 to 3 parallel ridges up to $2 \mathrm{~m}$ high, lay at elevations of 9 to $10 \mathrm{~m}, 15 \mathrm{~m}$ to $40 \mathrm{~m}$ from the cliff edge. Erosion occurred in three different locations: $(i)$ on the cliff where quarrying was important, $(i i)$ on the seaward face of the front ridge (iii) in the gully incised north of the ridge by exiting water (Fig. 11A). The identified tracks show that most of the blocks quarried from the cliff or removed on the exposed side of the front ridge moved toward the gully, which represents the main path of block 
displacements to the east of the island. As shown on Fig. 10A, this area corresponds to the main spillway during flooding processes of the island. The DoD of the centre (Fig. 9A) illustrates this morphodynamic processes with a net loss of $25 \mathrm{~m}^{3}$ corresponding to the largest block displacements in the whole island (accretion $\approx 50 \mathrm{~m}^{3}$, erosion $\approx 75 \mathrm{~m}^{3}$ ). Morphological changes occurred also on or between the three ridges. Two large blocks exceeding 3 tons were uplifted on the top of the front ridge. Another one weighing 3.1 tons moved from the base of the front ridge to the top of the second one $13 \mathrm{~m}$ inland. Several large blocks resting on the leeside of the front ridge were pushed toward the second one or transported over and deposited on the third one (Fig. 13).

The CS sector is the highest part of the island where striking changes occurred. The cliff-top of the subvertical cliffs reaches 10 to $13 \mathrm{~m}$ and is separated from the clusters by a 15 to $30 \mathrm{~m}$ wide wave-scoured platform where scattered blocks rest. No changes were observed on this platform during the winter storms. It is mainly beyond the seaward face of the clusters that erosion occurred. A 0.6 tons block buried in the turf on their leeside, $37 \mathrm{~m}$ inland from the cliff edge, was extracted and transported 6 meters inland. The DoD of centre-south indicates a negative sediment budget (accretion about $10 \mathrm{~m}^{3}$, erosion about $18 \mathrm{~m}^{3}$ ) due to the important soil erosion on the back of the wave-scoured platform (Fig. 10B).

The S sector can be divided into two sections. South of the promontory where the coast faces SW there are no cliffs. Dozens of blocks were transported parallel to the coast and deposited at 7 to $8 \mathrm{~m}$. North of the promontory, the coast faces west and is cut into cliffs. Back of the cliff-top, lying at $9 \mathrm{~m}$, a single arcuate ridge is separated from the cliff edge by a wavescoured platform widening northward. The erosion occurred mainly: (i) on the cliff were quarrying is important around 7-8 $\mathrm{m}$ and (ii) on the exposed face of the ridge, the southern 
end of it was completely spread inland. Erosion was limited above $10 \mathrm{~m}$. Deposition occurred mainly on the ridge or immediately behind, however many blocks were transported dozens of meters inland up to $10.5 \mathrm{~m}$ high. In this area the DoD shows balanced results between erosion and accretion (fig. 10C).

Concerning the resulting path of the transported blocks (Fig. 9B), 50\% of the displaced blocks followed two main directions: ESE and E, corresponding to the average direction of the incident waves after refraction over the nearshore bathymetry. Two secondary directions, ESE and ENE (20 and $14 \%$ resp.) also occurred, mainly on the southern tip of the island, and might be the result of local effects of the bathymetry on the wave propagation. The longest paths headed E (15\%) and ENE (5\%), the shortest ones headed ESE and SSE. However, it is difficult to assess whether these CTSDs trajectories were caused by one or several morphogenetic events. In this latter case, which is the most likely one given the recurrent EWL events during winter 2013-2014, the total path of the block resulted from several shorter intermediate paths with different directions, biasing the overall analysis.

\subsubsection{Intermediate changes observed in January and February 2014}

Observations obtained from ground photographs taken on January 14 and February 18, 2014, and from aerial photographs taken by kite on February 18, 2014 show that intermediate morphological and sedimentological changes occurred between December 2013 and January 2014, and others between January and February 2014. These observations confirmed that the series of storms during winter 2013-2014 caused morphosedimentary changes on several occasions. 
For instance, as shown in Fig. 14A, block \#6092 located in the C sector of the island moved a few meters inland between December 2013 and January 2014. This change can be attributed to the impact of the EWL events inventoried in January (Fig. 5-6-7) and most probably to storm Anne, during which the highest water levels were observed for this period. Similarly, during the period from January to February 2014, the blocks \#2650, \#6004, \#6005, \#6058 and \#6092, situated between the first and the second ridges in the $\mathrm{C}$ sector, moved for the first time in the winter (Fig. 14A, B, C, D). These changes can be attributed to the EWL events of February (Fig. 5-6-7) and most probably to storm Petra, during which the highest water levels were observed for this period. Finally, between February and April 2014, other changes were observed, such as the removal of blocks \#6004 and \#6005, located in the C sector of the island (Fig. 15C, D). They can be attributed to the most significant EWL event occurring during this period, namely Christine storm, on March 3-4. Note that some blocks (e.g. blocks \#6004, \#6005 and \#6092) moved several times during the winter. This implies that the trajectories of several blocks previously analyzed (Fig. 9) correspond in fact to the resultant of these successive displacements.

\section{Discussion}

As evidenced in many studies undertaken on sandy beaches and gravel barrier along the Western European coast (Matthews et al., 2014; Dissanayake et al., 2015; Blaise et al., 2015; Castelle et al., 2015; Masselink et al., 2016,), the winter 2013-2014 was particularly morphogenetic. Large morphological changes also occurred on rocky coasts, in south England (Earlie et al., 2015), on the Aran Island (Erdman et al., 2016) and on Banneg Island as shown in this paper. Before winter 2013-2014, the last significant CTSDs morphological changes observed on Banneg Island occurred on March 10, 2008, during Johanna storm (Fichaut and Suanez, 2011). The repeated monitoring conducted since this stormy event showed no 
significant morphosedimentary changes on the island, owing to the absence of morphogenetic conditions during this period. The specificity of winter 2013-2014 results from a succession of storms with repeated intensities unequalled since the winter 1989-1990. Indeed, between mid-December 1989 and mid-February 1990 fifteen storms had affected the western coast of Europe, from Brittany to the British Islands (McCallum and Norris, 1990; Betts et al., 2004). Banneg Island was also severely affected during this winter (Fichaut and Hallégouët 1989). In a context of potential increase of storminess in northern Europe (Zappa et al. 2013; Feser et al., 2015), it is likely that storm wave-induced quarrying and transport of cliff-top deposits will occur more frequently in Europe. Regarding the changes of Banneg's morphology, we may expect a significant increase of the erosion processes presently observed, with accelerated cliff recession, accentuated downwearing of the wave-scoured platforms, and a larger occurrence of boulder transport.

Our results clearly confirms the importance of mid-latitudes storm events for the investigation of CTSDs dynamics on exposed cliffs. Therefore, these results contradict the findings proposed by Regnault et al. (2010), suggesting that only tsunami waves (more specifically the Lisbon tsunami in 1755) could have generated the quarrying and/or transportation of large blocks of dozens of tons on the coasts of Molène archipelago and Ouessant Island. As shown in the present study, the quarrying of an 86 tons block shows that storm waves are powerfull enough to generate such processes (during Johanna storm, a clast weighing 42 tons was quarried from cliff-top and deposited upside down 7 m inland, see Fichaut and Suanez, 2011). Moreover, no argument proves the occurrence of tsunami waves in the Iroise Sea for the last centuries, including the Lisbon tsunami that was not recorded along the Brittany coasts (Lageat, 2014). 
From a spatial perspective, the north sector of the island was less impacted by the storms of winter 2013-2014 than the other sectors, as it was already the case during the Johanna storm (Fichaut and Suanez, 2011) and during the stormy winter 1989-1990 (Fichaut and Hallegouët, 1989). For example, only 13 blocks moved on the northern sector, while 250 and 299 block displacements were inventoried at the centre and south sectors of the island, respectively. This is mainly due to the presence of a rocky promontory that shelters this sector from the WSW incident waves, as evidenced by the lower Hs and water levels measured in this sector. The most important CTSDs morphological changes occurred mainly in the $\mathrm{C}$ and $\mathrm{S}$ sectors of the island, as shown by the number (250 and 299 respectively) and volumes of quarried and displaced blocks (Fig. 10). These morphological changes can be associated with a potentially high number of flooding events in these sectors estimated from the run-up analysis (Fig. 7). In the CS sector, morphological changes were far less important compared to the $\mathrm{C}$ and $\mathrm{S}$ sectors, despite the 86 tons block that was quarried from the cliff face and fell down (Fig. 11B). Nonetheless, the observed water levels and the number of estimated flooding occurrence (Fig. 10) were the highest in this sector. Comparing the morphological changes (Fig. 7) and flooding occurrences in the C, CS and S sectors, it thus appears that morphological changes are not systematically related to the number of estimated cliff-top submersions. We can therefore assume that the amount of removed and/or quarried blocks not only depend on the hydrodynamic conditions, but also on the lithostructural framework of the cliff. As reported by Suanez et al. (2009), the cliffs in the embayments (C and S sectors) are characterized by a very dense joint and fracture pattern providing a predisposition to produce a significant amount of relatively small clasts during extreme events. Conversely, on headlands (CS sector), where joint pattern is looser, the clasts size is larger and makes both quarrying and block transportation more difficult. 
From a temporal perspective, seven storm events associated with high water levels were identified as responsible for the observed morphosedimentary dynamics. These EWL events occurred during the first week of January, the first two weeks of February and on March 3-4 2014. The intermediate field surveys of January 14 and February 18, 2014 confirmed that CTSDs reworking occurred several times during the winter, and certainly in different directions. This multiphase dynamics was also evidenced by the two main directions (ESE and ENE) of the blocks displacements observed during winter 2013-2014 (Fig. 14A), and contrasts with the single ESE direction observed after Johanna storm on March 10, 2008 (Fig. 14B, Fichaut and Suanez, 2011). These authors attributed this ESE direction to the NW orientation of the waves measured at Les Pierres Noires buoy (Cariolet et al., 2010), as no wave measurements were available in front of Banneg Island in 2008. The DWR measurements carried out during winter 2013-2014 revealed that the mean wave direction 1.5 $\mathrm{km}$ off Banneg Island is generally comprised between $240-260^{\circ}$ and never exceeds $270^{\circ}$, even during NW storm episodes, which is due to the sheltering effect of Ouessant Island. Hence, the dominant ESE direction of blocks displacements observed during both Johanna storm and winter 2013-2014 is likely the result of the wave crest alignment along the SW-NE island axis, while the ENE block trajectories specific to winter 2013-2014 may be attributed to Ulla storms that generated unusual SW waves on Feburary 14-15, 2014.

The study conducted by Fichaut and Suanez (2011) after Johanna storm on 10 March 2008 allowed to characterize more precisely the dynamics of CTSDs. However, the methods implemented for this study were not sufficiently complete to get a comprehensive picture of all displacements of the blocks. Only 180 sockets in the bedrock and/or scars indicating movement of blocks were inventoried and no in-situ measurements were available to characterize hydrodynamic conditions responsible for these morphosedimentary processes. In 
the present study, the data provided by UAV deployment coupled to SfM photogrammetry improved the understanding of CTSDs morphodynamics by quantifying more accurately the kinematics and volumetric changes of CTSDs induced by storm waves during winter 20132014. As already demonstrated on boulder beaches (Pérez-Alberti and Trenhaile, 2015), the contribution of UAV survey data open the way for the quantification of rocky coasts sedimentary budget. Moreover, cross-comparison of high resolution orthophotographs appears particularly relevant for the accurate mapping of boulders kinematics, before and after storm events. Compared to terrestrial scanning, which is limited by the shadowing effect caused by rocky promontory and large boulders, UAV methods also appear more appropriate to generate accurate DEMs on large and rugged fields (Jaud et al., 2016). Finally, hydrogeomorphic studies coupling accurate boulder transport observations and high-frequency hydrodynamic measurements represent challenging applications for the numerical models of boulder transports (e. g. Kennedy et al., 2016).

\section{Conclusion}

This study provides new insights on the extreme wave conditions of the winter 2013-2014 and their strong impact on CTSDs dynamics on Banneg Island. The use of a combined hydrogeomorphologic data set revealed the link between the observation of recurrent morphological changes and the hydrodynamic conditions that caused them. The methodology based on UAS observations led to an analysis of CTSDs kinematics and volumetric changes over large spatial scales, which could not have been carried out only with DGPS field measurements and oblique ground photographs. However, as shown in this study, the coupling of the two approaches overcame the lack of information when weather conditions did not allow the deployment of airborne techniques. High frequency measurements of offshore and in-situ hydrodynamic conditions (waves and water levels) revealed a succession of energetic wave 
conditions, sometimes combined with high water levels. This data also enabled the calibration of an empirical run-up formula (Stockdon et al., 2006) to extrapolate maximum water levels from the local measurements in the upper swash zone. The combined analysis of observed wave and water levels, predicted maximum water levels, and morphosedimentary observations were used to clearly identify the storm events that caused CTSDs reworking during winter 2013-2014. Our study shows that morphogenetic events occurred at several occasion, namely during the first week of January, the two first weeks of February and on March 3-4, 2014. The centre sector of the island was the most impacted, and some blocks were shown to move several times, during these periods. This multiphase CTSDs dynamics was highlighted by the broad directional range of block trajectories. The two main directions, ESE and ENE, were explained by the incident wave propagation that reach the coast with a WNW direction (normal to the coast) or WSW directions in the case of unusually southerly storms such as Ulla storm, on Feburary 14, 2014. Finally, we conclude that the lithostructural context plays a crucial role in terms of cliff erosion and CTSDs production. Indeed, the centre-south sector of the island, characterized by loose joint pattern and large clasts, which suffered the highest waves and maximum water levels, did not display major morphosedimentary changes. On the other hand, the centre sector of Banneg Island that is characterized by lithostructural fragility, was the most impacted during winter 2013-2014, illustrating a slow process of fragmentation of the island into two parts. Future studies on similar environments would highly benefit from video monitoring (Holman and Guza, 1984; Holman et al., 1993; Raubenheimer et al., 1995) in order to overcome the lack of run-up measurements and the difficult deployment of airborne acquisition system during stormy conditions. 


\section{Acknowledgments}

We warmly thank the Réserve naturelle de la mer d'Iroise and its rangers $\mathrm{H}$. Maheo and D. Bourlès for allowing us to perform the measurements and helping in many ways our access to the site. Many thanks also go to the technical group at the French Navy Hydrographic and Oceanographic Institute (SHOM) who deployed and recovered the instruments. The Litto3D coastal digital elevation model co-produced by IGN and SHOM from numerous Lidar and MBES surveys was of great help in this project. This work is part of the research program PROTEVS (research contract 12CR6) funded by DGA and conducted by SHOM. This research was also supported by the "Laboratoire d'Excellence" LabexMER (ANR-10-LABX19) and co-founded by the French government under the program "Investissements d'Avenir", and the region of Brittany. We finally thank Jean-Pierre Boivin from the SHOM for providing kite aerial photographs taken on February 18, 2014. 


\section{References}

Agisoft, 2013. Agisoft photoscan user manual: professional edition Retrieved 09/02/2015 (http://www.agisoft.com/downloads/user-manuals/)

Ardhuin, F., Roland, A., Dumas, F., Bennis, A. C., Sentchev, Forget, P., A., Wolf, J., Girard, F., Osuna, P., Benoit, M., 2012. Numerical wave modeling in conditions with strong currents: Dissipation, refraction, and relative wind. Journal of Physical Oceanography, 42(12), 2101 2120.

Ardhuin, Pineau-Guillou, F.L., Fichaut, B., Suanez, S., 2011. Extreme set-up and run-up on steep cliffs (Banneg Island, France), paper presented at 12th International Workshop on Wave Hindcasting and Forecasting, and 3rd Coastal Hazard Symposium Kohala Coast,Hawai'i, HI. Autret, R., Suanez, S., Fichaut, B., Etienne, S., 2016. Elaboration d'une typologie des dépôts de blocs supratidaux de sommets de falaise de la péninsule de Reykjanes (Islande). Géomorphologie : relief, environnement, processus 22(1), 61-76.

Benoit, M., Lafon, F., Goasguen, G., 2006. Construction et exploitation d'une base de données d'états de mer le long des côtes françaises par simulation numérique sur 23 ans. Actes du colloque des IXe Journées Nationales Génie Civil - Génie Côtier, Brest, France, 1214 septembre 2006. In: L’Her J., Levacher D., Centre Français du Littoral (Eds.), Centre Français du Littoral, Nantes, 21-30.

Blaise, E., Suanez, S., Stéphan, P., Fichaut, B., David, L., Cuq, V., Autret, R., Houron, J., Rouan, M., Floc'h, F., Ardhuin, F., Cancouët, R., Davidson, R., Costa, S., Delacourt, C., 2015. Bilan des tempêtes de l'hiver 2013-2014 sur la dynamique de recul du trait de côte en Bretagne. Géomorphologie: relief, environnement, processus 21 (3), 267-292.

Betts N.L., Orford J.D., White D., Graham C.J., 2004. Storminess and surges in the southwestern approaches of the eastern North Atlantic: the synoptic climatology of recent extreme coastal storms. Marine Geology 210, 227-246. 
Carbone, F., Dutykh, D., Dudley, J. M., Dias, F., 2013. Extreme wave run-up on a vertical cliff. Geophysical Research Letters, 40(12), 3138-3143.

Cariolet, J. M., Costa, S., Caspar, R., Ardhuin, F., Magne, R., Goasguen, G., 2010. Aspects météo-marins de la tempête du 10 mars 2008 en Atlantique et en Manche. Norois. Environnement, aménagement, société, (215), 11-31.

Castelle, B., Marieu, V., Bujan, S., Splinter, K. D., Robinet, A., Sénéchal, N., Ferreira, S., 2015. Impact of the winter 2013-2014 series of severe Western Europe storms on a doublebarred sandy coast: Beach and dune erosion and megacusp embayments. Geomorphology, 238, 135-148.

Cox, R., Zentner, D. B., Kirchner, B. J., Cook, M. S., 2012. Block ridges on the Aran Islands (Ireland): recent movements caused by storm waves, not tsunamis. The Journal of geology, 120(3), 249-272.

Dissanayake, P., Brown, J., Karunarathna, H., 2015. Impacts of storm chronology on the morphological changes of the Formby beach and dune system, UK. Natural Hazards and Earth System Science, 15(7), 1533-1543.

Earlie, C. S., Young, A. P., Masselink, G., Russell, P. E, 2015. Coastal cliff ground motions and response to extreme storm waves. Geophysical Research Letters, 42(3), 847-854.

Erdmann, W., Kelletat, D., Scheffers, A. M., Haslett, S., 2015. Origin and Formation of Coastal Block Deposits at Galway Bay and the Aran Islands, Western Ireland. Springer.

Etienne, S., Paris, R., 2010. Block accumulations related to storms on the south coast of the Reykjanes Peninsula (Iceland). Geomorphology, 114(1), 55-70.

Feser, F., Barcikowska, M., Krueger, O., Schenk, F., Weisse, R., Xia, L., 2015. Storminess over the North Atlantic and northwestern Europe-A review. Quarterly Journal of the Royal Meteorological Society, 141(687), 350-382. 
Fichaut, B., Hallégouët, B., 1989. Banneg: une île dans la tempête. Penn ar Bed, 135, 36-43.

Fichaut, B., Suanez, S., 2008. Les blocs cyclopéens de l'île de Banneg (archipel de Molène, Finistère) : accumulations supratidales de forte énergie. Géomorphologie : relief, processus, environnement 1, 15-32.

Fichaut, B., Suanez S., 2011. Quarrying, transport and deposition of cliff-top storm deposits during extreme events: Banneg Island, Brittany. Marine Geology 283 (1-4), 36-55.

Goto, K., Miyagi, K., Kawana, T., Takahashi, J., Imamura, F., 2011. Emplacement and movement of blocks by known storm waves-field evidence from the Okinawa Islands, Japan. Marine Geology, 283(1), 66-78.

Hall, A. M., Hansom, J. D., Williams, D. M., Jarvis, J., 2006. Distribution, geomorphology and lithofacies of cliff-top storm deposits: examples from the high-energy coasts of Scotland and Ireland. Marine Geology, 232(3), 131-155.

Hansom, J. D., Barltrop, N. D. P., Hall, A. M., 2008. Modelling the processes of cliff-top erosion and deposition under extreme storm waves. Marine Geology, 253(1), 36-50.

Holman, R. A., Guza, R. T., 1984. Measuring run-up on a natural beach. Coastal Engineering, $8(2), 129-140$.

Holman, R. A., Sallenger, A. H., Lippmann, T. C., Haines, J. W., 1993. The application of video image processing to the study of nearshore processes. Oceanography, 6(3), 78-85.

Jaud, M., Passot, S., Le Bivic, R., Delacourt, C., Grandjean, P., Le Dantec, N., 2016. Assessing the Accuracy of High Resolution Digital Surface Models Computed by PhotoScan ${ }^{\circledR}$ and MicMac ${ }^{\circledR}$ in Sub-Optimal Survey Conditions. Remote Sensing, 8(6), 465.

Lau, A. A., Terry, J. P., Switzer, A. D., Pile, J., 2015. Advantages of beachrock slabs for interpreting high-energy wave transport: Evidence from Ludao Island in south-eastern Taiwan. Geomorphology, 228, 263-274. 
Lageat, Y., 2014. Note sur l'impact conjectural du tsunami de la Toussaint 1755 en Bretagne. Dynamiques Environnementales, 30, 19-28.

Le Gall, B., Authemayou, C., Ehrhold, A., Paquette, J. L., Bussien, D., Chazot, G., Aouizerat, A., Pastol, Y., 2014. LiDAR offshore structural mapping and U/Pb zircon/monazite dating of Variscan strain in the Leon metamorphic domain, NW Brittany. Tectonophysics, 630, 236250.

Masselink, G., Scott, T., Poate, T., Russell, P., Davidson, M., Conley, D., 2015. The extreme 2013/2014 winter storms: hydrodynamic forcing and coastal response along the southwest coast of England. Earth Surface Processes and Landforms.

Masselink, G., Castelle, B, Scott, T., Dodet, G., Suanez, S., Jackson, D., Floc'h, F., 2016. Extreme wave activity during 2013/2014 winter and morphological impacts along the Atlantic coast of Europe. Geophysical Research Letters.

Matthews, T., Murphy, C., Wilby, R.L., Harrigan, S., 2014. Stormiest winter on record for Ireland and UK. Nature Climate Change, 4, 738-740.

McCallum E., Norris W.J.T., 1990. The storms of January and February 1990. The Meteorological Magazine 119, 201-210.

Nandasena, N.A.K., Paris, R., Tanaka, N., 2011. Reassessment of hydrodynamic equations: minimum flow velocity to initiate block transport by high energy events (storms, tsunamis). Marine Geology 281, $70-84$.

Naylor, L. A., Kennedy, D. M., Stephenson, W. J., 2014. Synthesis and conclusion to the rock coast geomorphology of the world. Geological Society, London, Memoirs, 40(1), 283-286.

Naylor, L. A., Stephenson, W. J., Smith, H., Way, O., Mendelssohn, J., Cowley, A., 2016. Geomorphological control on block transport and coastal erosion before, during and after an extreme extra-tropical cyclone. Earth Surface Processes and Landforms. 
Nott, J., 2003. Waves, coastal block deposits and the importance of the pre-transport setting. Earth and Planetary Science Letters 210, 269-276.

Paris, R., Naylor, L. A., Stephenson, W. J., 2011. Blocks as a signature of storms on rock coasts. Marine Geology, 283(1), 1-11.

Pérez-Alberti, A., Trenhaile, A. S., 2015. An initial evaluation of drone-based monitoring of boulder beaches in Galicia, north-western Spain. Earth Surface Processes and Landforms, 40(1), 105-111.

Raubenheimer, B., Guza, R. T., Elgar, S., Kobayashi, N., 1995. Swash on a gently sloping beach. Journal of Geophysical Research: Oceans, 100(C5), 8751-8760.

Regnauld, H., Oszwald, J., Planchon, O., Pignatelli, C., Piscitelli, A., Mastronuzzi, G., Audevard, A., 2010. Polygenetic (tsunami and storm) deposits? A case study from Ushant Island, western France. Zeitschrift für Geomorphologie, Supplementary Issues, 54(3), $197-$ 217.

Richmond, B.M., Morton, R.A., 2007. Coral-gravel storm ridges: examples from the tropical Pacific and Caribbean. Proceedings Coastal Sediments 2007, 572-583.

Ruessink, B.G., Kleinhans, M.G., Van den Beukel, P.G.L., 1998. Observations of swash under highly dissipative conditions. Journal of Geophysical Research: Oceans, 103(C2), 3111-3118.

Scheffers, A. M., Scheffers, S. R., Kelletat, D. H., Squire, P., Collins, L., Feng, Y., Zhao, JX., Joannes-Boyau, R., Matthias May, S., Schellmann, G., Freeman, H., 2012. Coarse clast ridge sequences as suitable archives for past storm events? Case study on the Houtman Abrolhos, Western Australia. Journal of Quaternary Science, 27(7), 713-724.

Sheremet, A., Staples, T., Ardhuin, F., Suanez, S., Fichaut, B., 2014. Observations of large infragravity wave run-up at Banneg Island, France. Geophysical Research Letters, 41(3), 976982. 
SHOM, 2014. Références altimétriques maritimes - Ports de France métropolitataine et d'outre-mer. Côtes du zéro hydrographique et niveaux caractéritistiques de la marée. Service Hydrographique et Océanographique de la Marine, Brest, 112 p.

Stockdon, H. F., Holman, R. A., Howd, P. A., Sallenger, A. H., 2006. Empirical parameterization of setup, swash, and run-up. Coastal engineering, 53(7), 573-588.

Suanez, S., Fichaut B., Magne R., 2009. Cliff-top storm deposits on Banneg Island, Brittany, France: Effects of giant waves in the Eastern Atlantic Ocean. Sedimentary Geology 220 (1-2), $12-28$.

Suanez, S., Cancouët, R., Floc'h, F., Blaise, E., Ardhuin, F., Filipot, J. F., Cariolet, J-M., Delacourt, C., 2015. Observations and predictions of wave run-up, extreme water levels, and medium-term dune erosion during storm conditions. Journal of Marine Science and Engineering, 3(3), 674-698.

Wadey, M.P., Haigh, I.D., Brown, J.M., 2014. A century of sea level data and the UK's 2013/14 storm surges: an assessment of extremes and clustering using the Newlyn tide gauge record. Ocean Science, 10, 1031-1045.

Williams, D. M., Hall, A. M., 2004. Cliff-top megaclast deposits of Ireland, a record of extreme waves in the North Atlantic_-storms or tsunamis? Marine Geology, 206(1), 101-117. Wheaton, J. M., Brasington, J., Darby, S. E., Sear, D. A., 2010. Accounting for uncertainty in DEMs from repeat topographic surveys: improved sediment budgets. Earth Surface Processes and Landforms 35, 136-156.

Zappa, G., Shaffrey, L. C., Hodges, K. I., Sansom, P. G., Stephenson, D. B., 2013. A multimodel assessment of future projections of north Atlantic and European extratropical cyclones in the CMIP5 climate models. Journal of Climatology, 26, 5846-5862. 


\section{ACCEPTED MANUSCRIPT}

\section{Figure 1}
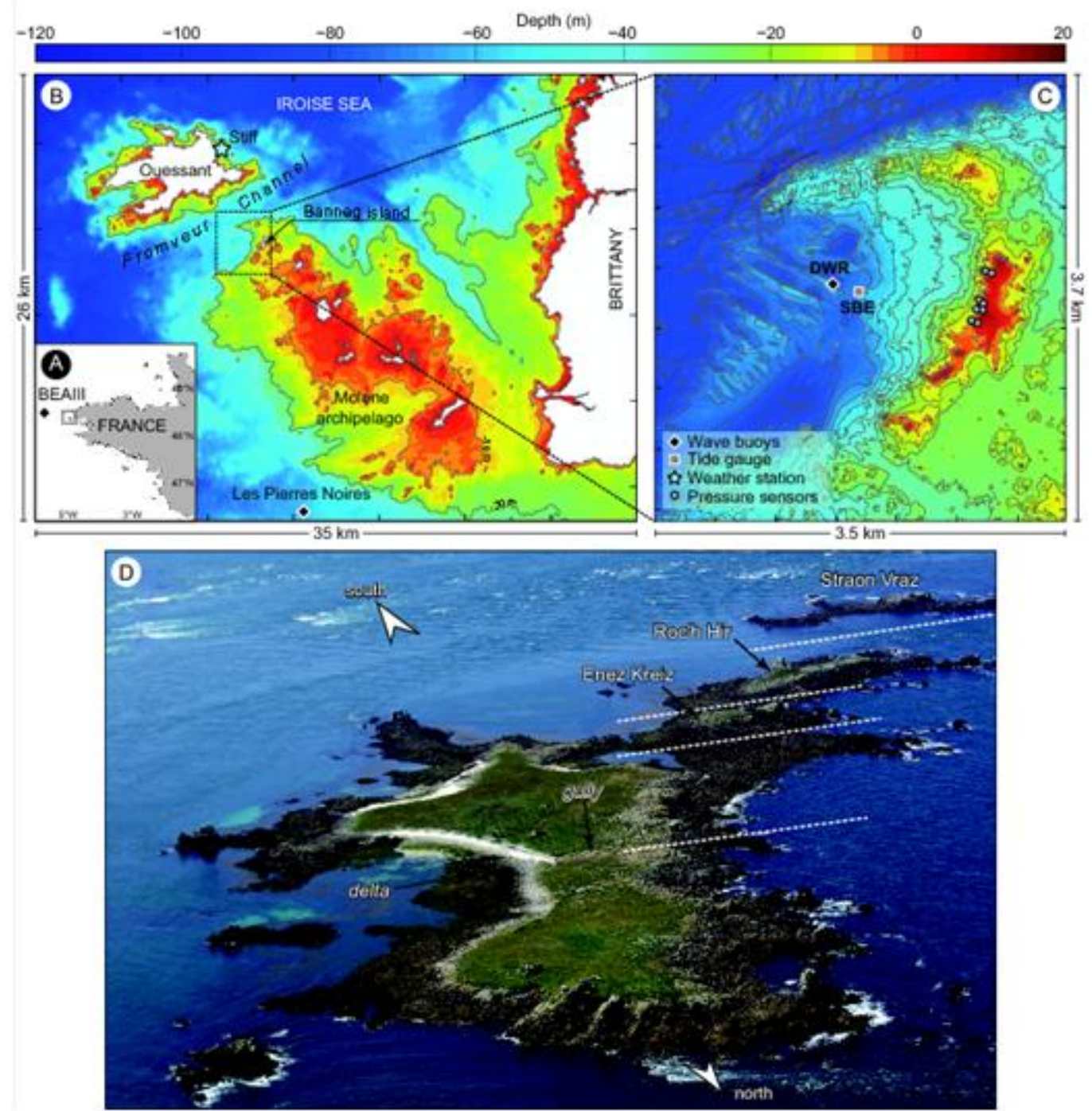


\section{ACCEPTED MANUSCRIPT}

\section{Figure 2}

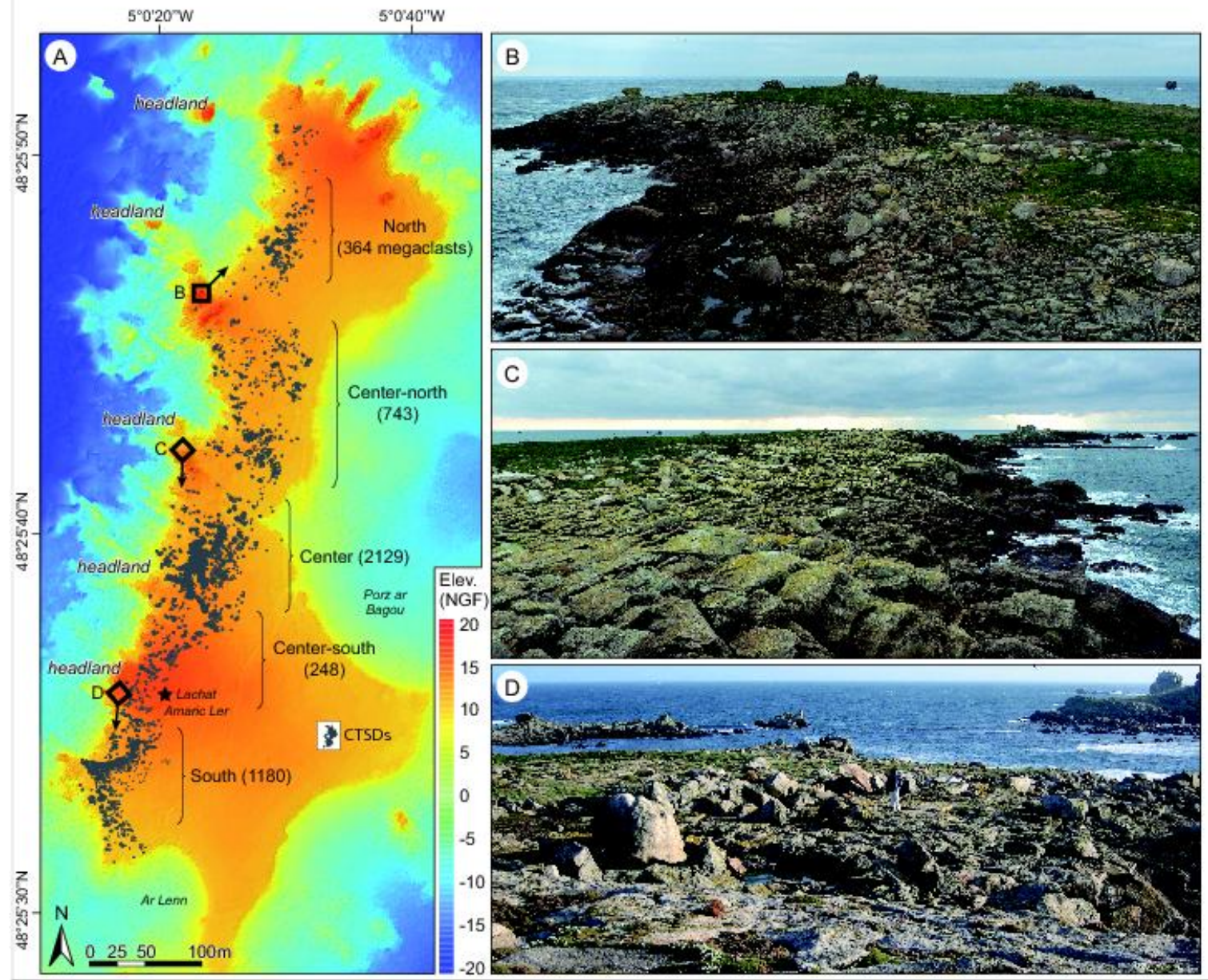


Figure 3

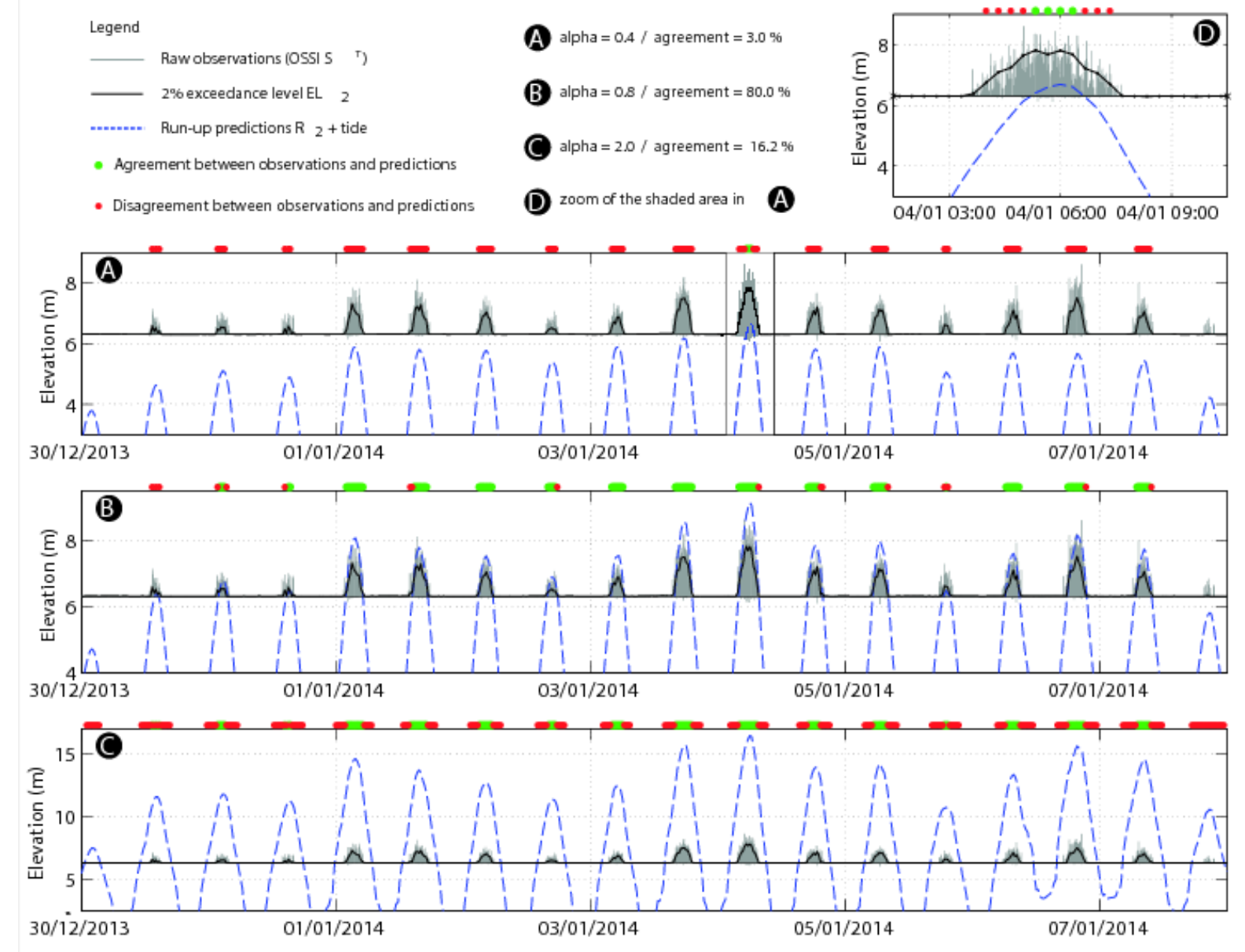


Figure 4
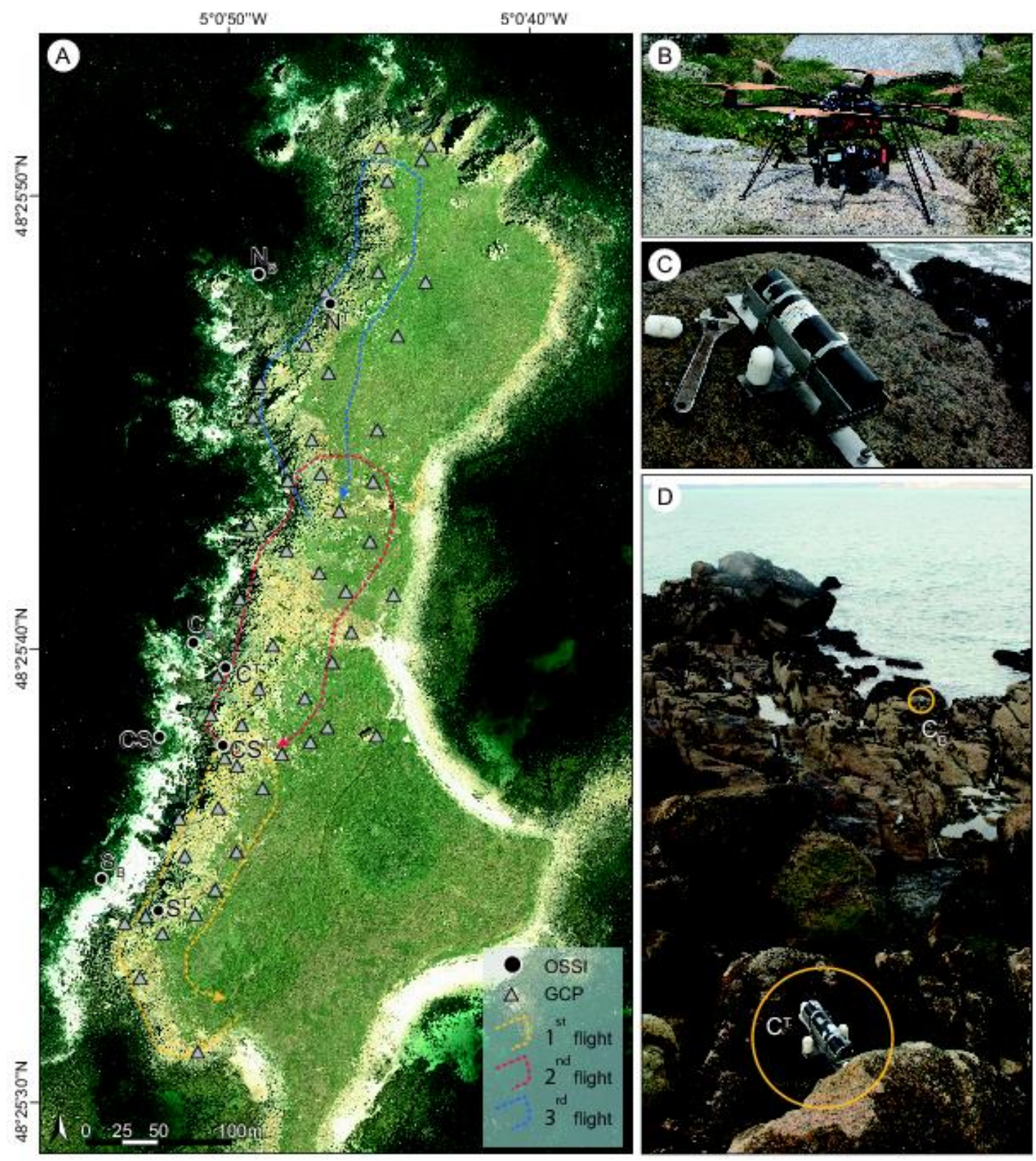
Figure 5

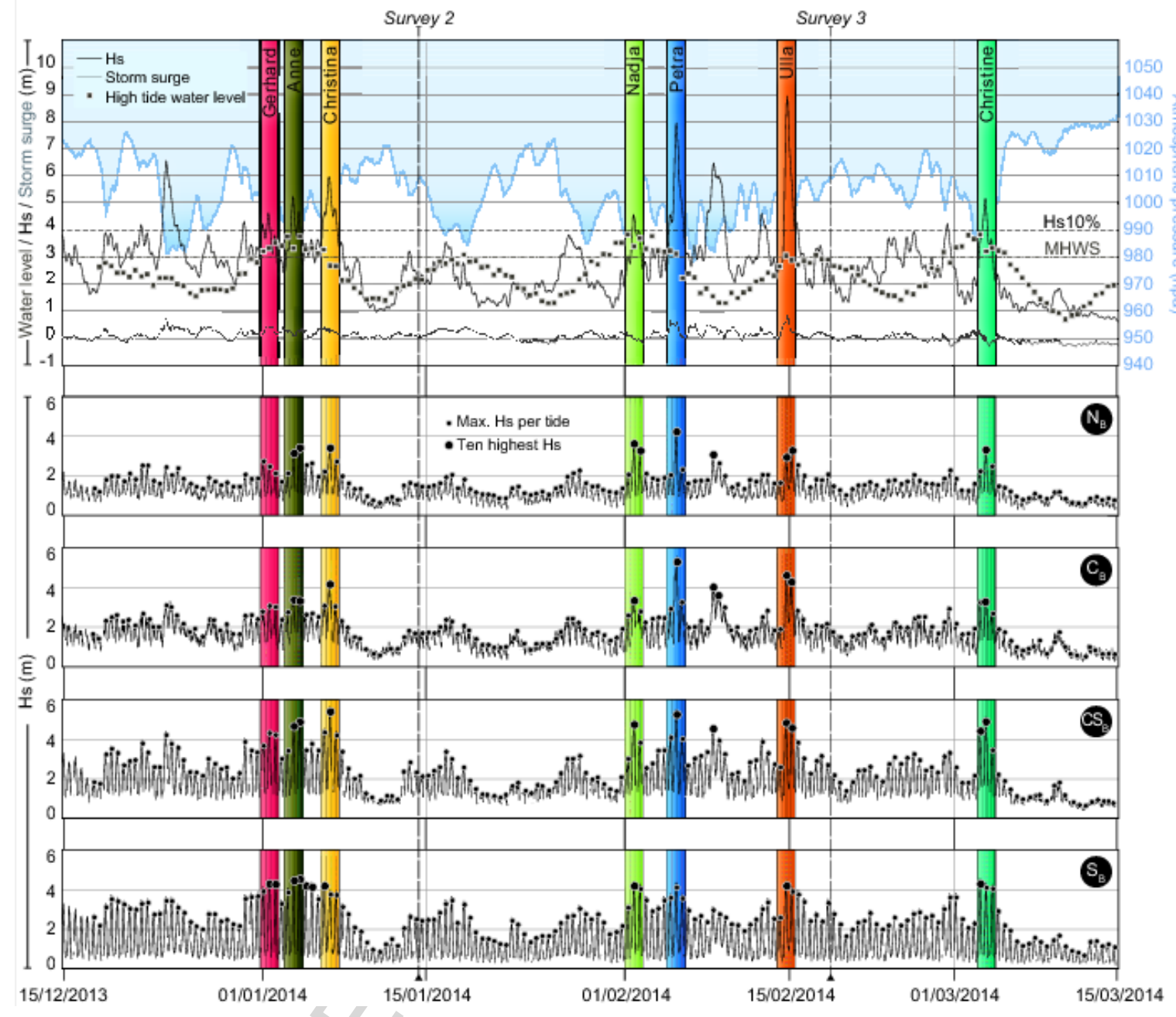


Table 1: Characteristics of the UAS-based surveys

\begin{tabular}{cccccccc}
\hline $\begin{array}{c}\text { UAS } \\
\text { Survey }\end{array}$ & $\begin{array}{c}\text { Flight } \\
\text { altitude }\end{array}$ & $\begin{array}{c}\text { Area } \\
\text { (ha) }\end{array}$ & $\begin{array}{c}\text { Nbr. } \\
\text { images }\end{array}$ & $\begin{array}{c}\text { Ground } \\
\text { resolution }\end{array}$ & $\begin{array}{c}\text { Nbr. } \\
\text { GCP }\end{array}$ & $\begin{array}{c}\text { DEM } \\
\text { resolution }\end{array}$ & RMSE \\
\hline $01 / 09 / 2013$ & $84 \mathrm{~m}$ & 7.5 & 250 & $0.018 \mathrm{~m} / \mathrm{pix}$ & 50 & $0.03 \mathrm{~m} / \mathrm{pix}$ & $0.041 \mathrm{~m}$ \\
\hline $04 / 08 / 2014$ & $81 \mathrm{~m}$ & 10 & 220 & $0.018 \mathrm{~m} / \mathrm{pix}$ & 50 & $0.03 \mathrm{~m} / \mathrm{pix}$ & $0.046 \mathrm{~m}$ \\
\hline
\end{tabular}


Table 2: Characteristics of the seven largest EWL events recorded during winter 2013-2014

Storm Period of activity near Max. Peak Mean High tide water Lag between max. Hs name $^{1} \quad$ Banneg Island $\quad$ Hs (m) period (s) dir. $\left(^{\circ}\right)$ level (m AMSL) and high tide (min)

\begin{tabular}{ccccccc}
\hline Gerhard & $31 / 12 / 2013-02 / 01 / 2014$ & 4.8 & 12.2 & 255 & 3.3 & 20 \\
Anne & $02 / 01 / 2014-04 / 01 / 2014$ & 5.4 & 14.5 & 261 & 3.3 & 20 \\
Christina & $06 / 01 / 2014-07 / 01 / 2014$ & 6.3 & 17.2 & 257 & 2.7 & 40 \\
Nadja & $31 / 01 / 2014-02 / 02 / 2014$ & 5.0 & 18.9 & 258 & 3.4 & 40 \\
Petra & $04 / 02 / 2014-06 / 02 / 2014$ & 8.8 & 17.3 & 254 & 3.1 & 100 \\
Ulla & $13 / 02 / 2014-15 / 02 / 2014$ & 9.7 & 16.9 & 230 & 3.1 & 220 \\
Christine & $02 / 03 / 2014-04 / 03 / 2014$ & 5.4 & 19.0 & 257 & 2.2 &
\end{tabular}

\footnotetext{
${ }^{1}$ The storm names correspond to the associated low-pressure system which are named at the Institute of Meteorology of Berlin
} 
Table 3: Percentage of agreement between measurements and predictions for calibration coefficient $\alpha$ ranging from 0.4 to 2.0

\begin{tabular}{cccccccccccccccccc}
$\alpha$ & 0.4 & 0.5 & 0.6 & 0.7 & 0.8 & 0.9 & 1.0 & 1.1 & 1.2 & 1.3 & 1.4 & 1.5 & 1.6 & 1.7 & 1.8 & 1.9 & 2.0 \\
\cline { 2 - 13 } $\mathrm{N}$ & 47.2 & 69.2 & $\mathbf{7 4 . 5}$ & 66.3 & 54.4 & 44.9 & 37.8 & 33.2 & 29.8 & 27.0 & 24.9 & 23.0 & 21.6 & 20.4 & 19.4 & 18.5 & 17.8 \\
$\mathrm{C}$ & 7.6 & 20.2 & 37.8 & 58.2 & $\mathbf{6 8 . 6}$ & 65.3 & 56.2 & 46.0 & 38.3 & 32.3 & 27.8 & 24.1 & 21.7 & 19.7 & 18.2 & 16.7 & 15.6 \\
$\mathrm{CS}$ & 0.0 & 0.0 & 0.0 & 3.6 & 8.4 & 15.6 & 25.5 & 34.7 & 49.4 & 59.8 & 69.2 & $\mathbf{7 2 . 4}$ & 68.5 & 61.4 & 53.4 & 46.6 & 41.5 \\
$\mathrm{~S}$ & 3.0 & 10.5 & 42.9 & 60.4 & $\mathbf{8 0 . 0}$ & 71.7 & 58.6 & 48.9 & 39.5 & 33.6 & 28.2 & 25.1 & 22.4 & 20.2 & 18.7 & 17.5 & 16.2
\end{tabular}

